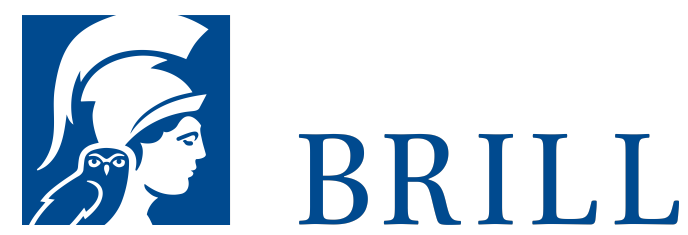

\title{
Stilling the Storm
}

Contemporary Responses to Mark 4.35-5.1

Author:John Vincent

Most books about Jesus and the Gospels deal with texts, background, culture and authorial intentions. A new approach to the Gospels called Practice Interpretation puts the emphasis on the actual happenings behind the Gospel stories - on what first hearers might have made of them, and on what contemporary disciples today make of them. The concern of the studies in this series is with the "use" of a Gospel story by disciples today, and of its "influence" on them.

In this ground-breaking collection, the first in the Practice Interpretation series, people from many different situations describe what the story of Jesus Stilling the Storm actually "sparked off" in their lives.

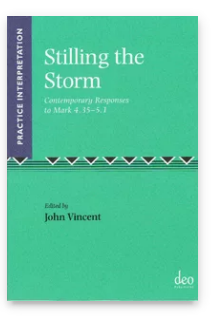

Language:

English

Subjects:

General,

Theology and

World

Christianity

Publisher: Brill

Series:

Practice

Interpretation,

Volume: 1

E-Book (PDF)

Released online:

29 Jan 2020

ISBN: 978-90-

04-39728-6

List price

USD \$9o.oo

Paperback

Publication date:

o1 Jan 2011

ISBN: 978-1-

905679-17-1

List price

USD \$30.0о 
Rev. Dr. John Vincent, D.Theol. 196o, Basel, is Honorary Lecturer in Biblical Studies at the University of Sheffield. He is the editor of Mark: Gospel of Action and joint author of The Drama of Mark and The City in Biblical Perspective. He is a Methodist minister, and married with three grown-up children.

For more information see brill.com

Order information: Order online at brill.com +44330 3330049 | customerservices@brill.com Submission information: brill.com/authors

Titles published by Brill | Fink, Brill | mentis or Brill|Schöningh: +49(o)71 5413279216 | brill@brocom.de 